\title{
Effect of Solid Wastes Composition and Confinement Time on Methane Production in a Dump
}

\author{
Carlos González ${ }^{1}$, Otoniel Buenrostro ${ }^{* *}$, Liliana Marquez ${ }^{1}$, Consuelo Hernández ${ }^{2}$, Edgar Moreno ${ }^{3}$, \\ Fabián Robles ${ }^{4}$
}

\footnotetext{
${ }^{1}$ Agronomics and Forestry Research Institute, Universidad Michoacana de San Nicolás de Hidalgo, Morelia, Mexico; ${ }^{2}$ Technological Institute of Toluca, Toluca, Mexico; ${ }^{3}$ Technological Institute of Morelia, Morelia, Mexico; ${ }^{4}$ Interdisciplinary Professional Unit of Biotechnology, Instituto Politécnico Nacional, Mexico City, Mexico.

E-mail: "otonielb@umich.mx
}

Received September 21 ${ }^{\text {st }}, 2011$; revised October $23^{\text {rd }}, 2011$; accepted November $25^{\text {th }}, 2011$.

\begin{abstract}
In developing countries, illegal dump structures or even some landfills do not include methane collecting systems, even if local environmental laws exist. In this condition, the greenhouse gas escapes to the atmosphere uncontrolled and practical solutions to tackle this problem are not obvious. To make a solution approachable, first-hand reliable data from dump emissions are required as starting point. The methane production is not homogeneous throughout the dump, therefore to estimate its global methane emissions, various representative gas monitoring sites distributed along the dump becomes necessary. This research work presents the measures of biogas emissions collected in the final disposal site located at Morelia (Mexico), along with an evaluation of the organic fraction and confinement time participation on biogas production. Biogas emission data were taken with a portable analyzer from 49 ventilation pipes for 52 weeks. For the composition and degradability analysis of solid wastes, the required samples have been collected from 16 sites. The results show a heterogeneous composition of solid wastes: 38 separate components are present, from those, 19 belong to organic categories and 28 of total components accounts for almost $99 \%$ of the waste. The mean biogas concentration detected was: $45.5 \% \mathrm{CH}_{4}, 32.4 \% \mathrm{CO}_{2}, 3.1 \% \mathrm{O}_{2}$, and $18.9 \%$ balance gas (i.e., $\mathrm{N}_{2}$, $\mathrm{CO}$ or $\mathrm{H}_{2} \mathrm{~S}$ ). The ANOVA procedure clearly corroborated the influence of composition, biodegradability and time of confinement of solid wastes on the production of methane, despite the deficiencies in the final soil layer cover in these sites.
\end{abstract}

Keywords: Mexico, Biodegradability, Emissions, Biogas, Methane

\section{Introduction}

Intergovernmental agencies worldwide are making attempts to create awareness about the contribution to global warming of landfill gas emissions from decomposing municipal solid wastes (MSW), recommending the use of biogas emissions as a source of alternative energy instead of their release to the atmosphere [1]. The amount of landfill gas generated largely depends on climatic conditions, geography, waste characteristics and other local factors [2]. Several researchers have identified the factors influencing the degradation of MSW and have assessed their individual effects on the methane production. These factors include presence or absence of oxygen and hydrogen [3-5]; temperature [6,7]; MSW confinement time [8]; MSW field capacity and hydraulic retention time [9-11]; compaction and compressibility of MSW [12]; $\mathrm{pH}[13,14]$; type of material used as final cover layer and the codisposition of wastes from the construction and demolition industry $[15,16]$; humidity content and water flow $[17,18]$ and; the use of inoculants such as biosolids and compost, and leachate recycling [19-26]. Although the aforementioned factors are interdependent, [27] identified $\mathrm{pH}$ and humidity content as being most critical, whereas [28] emphasized humidity and nutrient contents as the main factors affecting the stabilization of MSW. However, only the solid wastes containing cellulose are degraded in a landfill, such as food and yard wastes and two thirds of the paper and cardboard; the degradation of other materials is often incomplete [29].

There is clearly a need to extend the knowledge on biogas emissions in MSW disposal sites in order to opti- 
mize measures for landfill gas capture and to minimize emissions to the environment [30], but such information is still very limited in developing countries, and when available, comparisons and the determination of precise data is difficult. The available information derives from short-term studies made in final disposal sites that have heterogeneous composition, different climatic conditions, while management and measuring techniques vary widely [2,31-33]. Table 1 shows the results of some studies of biogas composition.

In the present research the composition of landfill gas emission was analyzed at the final disposition site in the city of Morelia (Mexico), the scope was to determine the effect of MSW composition in the production of biogas. The specific objectives were: 1) To determine the physicochemical characteristics of confined MSW, and 2) to study the amount and composition of the biogas generated in the studied site.

\section{Materials and Methods}

\subsection{Description of the Studied Site and Sampling of Solid Waste}

The present study was conducted in final disposal site that was closed for operation four years ago, after 20 years of activity. The dump is located $15 \mathrm{~km}$ west of Morelia, the capital city of the state of Michoacán, in Mexico $\left(19^{\circ} 41^{\prime} 40^{\prime \prime} \mathrm{N}, 101^{\circ} 20^{\prime} 54^{\prime \prime} \mathrm{W}\right)$, at an elevation of 2075 m.a.s.1. (Figure 1). The predominant climate in the area is of the temperate subtype Cwa, with a mean annual temperature of $18.7^{\circ} \mathrm{C}$, intermediate humidity, a summer rainfall regime of $700-1000 \mathrm{~mm}$ and an average of $5 \mathrm{~mm}$ of winter precipitation. The site has an extension of 17 ha, an irregular topography, an approximate slope of $15^{\circ}$; disposal cells have a maximum depth of $10.1 \mathrm{~m}$ and the estimated amount of deposited MSW is of 3,859,642 t [34]. At the time of its closure, 49 venting pipes were installed at a $3 \mathrm{~m}$ depth.

\subsection{Sampling and Characterization of Solid Waste Composition}

The study area was divided into four quadrants according to the confinement period of MSW, the oldest being quadrant I and the more recent, quadrant IV. Using a simple random design, 16 boreholes were perforated at a depth of $3 \mathrm{~m}$ and from each one approximately $4 \mathrm{~kg}$ of refuse were collected in transparent plastic bags. The

Table 1. Composition of landfill gas (LFG) in different world regions (\% volume).

\begin{tabular}{|c|c|c|c|c|c|c|c|c|}
\hline \multirow[b]{2}{*}{ Landfill location } & \multirow[b]{2}{*}{ Year } & \multicolumn{4}{|c|}{ LFG composition } & \multirow[t]{2}{*}{$\mathbf{S}$} & \multirow[t]{2}{*}{ D } & \multirow[t]{2}{*}{$\mathbf{W}$} \\
\hline & & $\mathrm{CH}_{4}$ & $\mathrm{CO}_{2}$ & $\mathbf{O}_{2}$ & Balance & & & \\
\hline P. de Montaña, Mexico & $2000-2001$ & 46 & 34.6 & 2.6 & 16.86 & 16 & $\mathrm{~S} / \mathrm{D}$ & Horizontal \\
\hline Samutprakan, Thailand & 2004 & 50.6 & 38.9 & 1.1 & 8.5 & 3 & 50 & Horizontal \\
\hline Site of Study & $2010-2011$ & 45.5 & 32.4 & 3.1 & 18.9 & 7 & 3 & Vertical \\
\hline
\end{tabular}

Sources: [2,31,32]. S (Sampling period (months)); D (Depth (meters)); W (Wells).

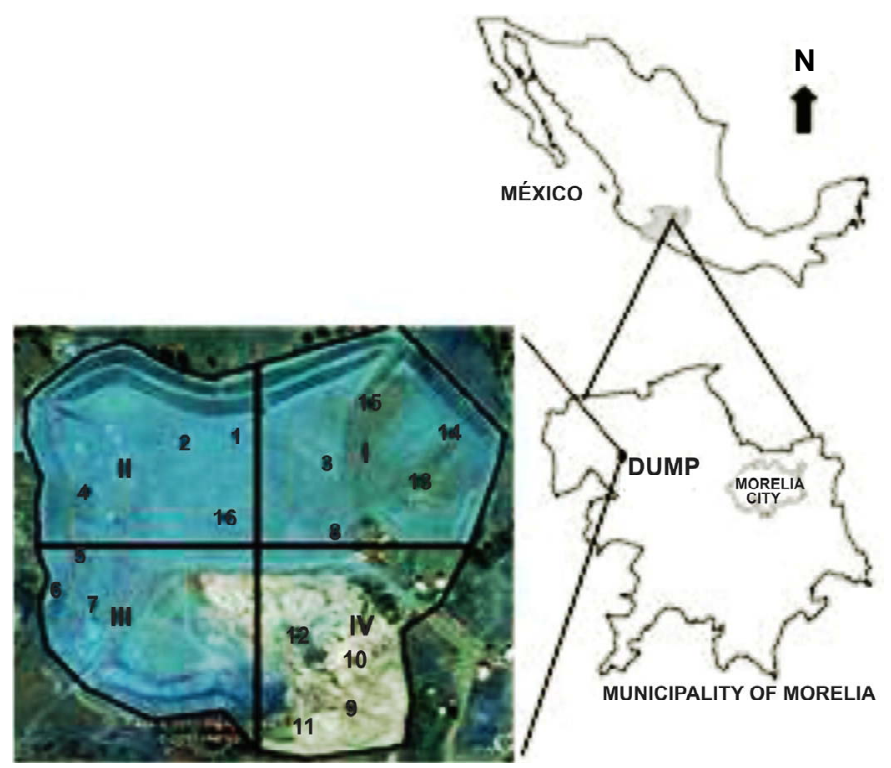

Figure 1. Location of the Morelia, Michoacán dump. 
numbers of boreholes and venting pipes in each quadrant are shown in Table 2.

\subsection{Physical and Chemical Analyses of Solid Waste Samples}

Physical and chemical analyses of samples were conducted in triplicate. Samples were grinded to homogenize the components to one inch fractions. These analyses included: characterization of waste components (NOM-AA22-1985) [35], temperature (NMX-AA-25-1984) [36], $\mathrm{pH}$ (NMX-AA-25-1984) [36], moisture content (NMX-AA016-1984) [37], total solids (TS) (APHA, 1998), volatile solids (VS) [38], ashes (NMX-AA-018-1984) [39] and methane emission (using a GEM-2000 plus (Landtec) portable analyzer).

\subsection{Measurement of Biogas Emissions}

Measurement of biogas emissions were made in the 49 venting pipes using a GEM-2000 plus (Landtec) portable analyzer. Measurements for methane $\left(\mathrm{CH}_{4}\right)$, carbon dioxide $\left(\mathrm{CO}_{2}\right)$, oxygen $\left(\mathrm{O}_{2}\right)$ and hydrogen sulfide $\left(\mathrm{H}_{2} \mathrm{~S}\right)$ were periodically made during 52 weeks.

Measurements were made during morning time (between 9:00 AM and 13:00 PM) to assure less interference from external factors such as changes in humidity and temperature, placing both plastic connectors of the analyzer inside venting pipes.

\subsection{Data Statistical Analysis}

Field and laboratory data from the physical and chemical analyses of composition of residues and of emission of methane in the dump were captured in the program Excel (Microsoft Office XP). The JMP program (Version: 6.0. SAS Inc. Institute, 2005) was used for the statistical analysis. Descriptive statistics and three series of one-way analysis of variance (ANOVA) were performed to establish the influence between the production of gas and the surveyed variables. Those variables showing a statistically significant difference were analyzed by means of the Tukey test.

\section{Results and Discussion}

\subsection{Composition of Solid Wastes Samples}

The composition of solid waste included 38 components,

Table 2. Number of wells and venting pipes in each quadrant of the study site.

\begin{tabular}{ccc}
\hline Quadrant & Boreholes & Ventilation pipes \\
\hline I & 5 & 15 \\
II & 4 & 11 \\
III & 3 & 11 \\
IV & 4 & 12
\end{tabular}

as described in the Mexican norm. Table 3 shows a high heterogeneity of results among quadrants. It is likely that these differences result from the different factors such as: a seasonal variation in the consumption and the modification in consumption patterns due to economic and demographic challenges experienced in the country $[40,41]$. Table 3 also shows a variety of the more abundant components of the 38 categories, of which, food waste/Unidentifiable fraction was dominant; it is noteworthy that the organic fraction content is inversely proportional to the confinement period of the solid residues, showing the influence in the organic fraction content of time of disposition of solid wastes in the site. Oldest quadrants have a lower content of organic waste, as can be seen in the quadrant I to the more recent (quadrant IV).

Of the total solid waste composition in the site of study, the organic fraction (fine residue, food and yard wastes, hard plant fiber, bone, wood, feces, cardboard, leather, paper, cloth, shoes, hair, coating and wax) averaged $63 \%$, a proportion that is relatively high, which reflects that although the city of Morelia has experienced economic challenges these have not been widespread for all the population, and also that a rural life style consumer pattern prevails.

Also, despite the implementation in Morelia of MSW separation programs, some recyclable components such as cardboard, rigid and film plastics, and glass, continue to be elevated in the solid waste stream. It was also observed that only those materials having high economic value and demand, such as aluminum, polyethylene terephthalate

Table 3. Composition of solid waste in the study site (\%, w/w, fresh basis).

\begin{tabular}{ccccc}
\hline & \multicolumn{5}{c}{ Quadrant } \\
\hline Category & I & II & III & IV \\
& & & & \\
Food Waste/Unidentifiable fraction ${ }^{*}$ & 31.6 & 36.3 & 66.4 & 60.3 \\
Paper and Cardboard & 7.1 & 10.2 & 4.4 & 3.9 \\
Yard Waste & 3.3 & 2.3 & 4.7 & 1.5 \\
Wood & 2.2 & 1.4 & 0.0 & 2.4 \\
Cloth & 1.3 & 1.5 & 4.1 & 2.7 \\
Other Organics & 1.2 & 1.5 & 0.4 & 0.6 \\
Diapers & 4.6 & 5.3 & 1.4 & 2.6 \\
Metals & 3.2 & 3.7 & 0.1 & 0.1 \\
Glass and Ceramics & 4.9 & 2.5 & 2.2 & 3.6 \\
Plastics & 16.8 & 21.2 & 9.5 & 12.2 \\
Stones & 19.7 & 13.2 & 6.8 & 8.0 \\
Other Inorganic & 4.3 & 0.3 & 0.0 & 2.1 \\
\hline
\end{tabular}

*Organic components difficult to identify due to the stage of degradation; ** Organic components such as cotton, leather, bone, wood, etc; ${ }^{* * *}$ Inorganic components, such as synthetic fibers, cellophane, aluminum foil, electrical material, cigarette butts, modeling clay, and shoes, etc. 
and ferrous materials have been diminishing their amounts with respect to previously measurements in the solid waste stream [40].

\subsection{Results of Physical and Chemical Analyses of Solid Waste Samples}

An increment in temperature was observed related to the depth of the layer and to the season (results no shown). Nonetheless all the studies boreholes presented mesophilic temperatures $\left(35^{\circ} \mathrm{C}\right.$ to $40^{\circ} \mathrm{C}$ ) (Table 4) during the sampling period and methane production was detected in all ventilation pipes in the site, which is in agreement with the report of [42] that a mesophilic range of temperature is a critical factor for the optimal degradation of the organic fraction of the wastes.

Moisture values ranged between $29 \%-38 \%$ for all boreholes, commonly this value is $25 \%-60 \%$ [42], and is linked to its composition. However, obtained data did not show a clear difference in the moisture content between the quadrants within the $3 \mathrm{~m}$ depth at which solid wastes samples were taken.

Solid waste $\mathrm{pH}$ values were detected in the range of 8 8.4 (Table 4), which is indeed a suitable range for the optimal degradation of solid wastes; $\mathrm{pH}$ is an important parameter in the optimum decomposition of solid wastes because the acidic/basic conditions influence the methanogenic phase [19].

The results of TS showed values of between $62 \%$ $68 \%$, the highest being concentrated in stratum III, which is related to the lower content of humidity in that level.

Volatile solid values ranged from 33\% - 56\% (Table 4), an ample range that reflects the level of degradation of MSW among quadrants. Higher values of volatile solids and of the organic fraction in quadrant IV are showing a relation with the stage of degradation of the organic contents and the confinement time of the solid wastes. The volatile solid content has been used to express the total organic matter present in solid wastes. According to [43], volatile solids are a reliable parameter to indicate the degradation of the organic materials throughout time, and

Table 4. Physical and chemical characteristics of waste samples.

\begin{tabular}{ccccc}
\hline & \multicolumn{5}{c}{ Quadrant } \\
\hline Parameters & I & II & III & IV \\
Physical Characteristics & & & & \\
Temperature $\left({ }^{\circ} \mathrm{C}\right)$ & 35.7 & 28.5 & 28.3 & 36.9 \\
$\mathrm{pH}$ & 8.4 & 8.4 & 8.3 & 8.0 \\
Moisture Content (\%) & 34.2 & 35.0 & 37.1 & 31.7 \\
Chemical Characteristics & & & & \\
Total Solids (\% w/w) & 65.8 & 65.0 & 62.9 & 68.2 \\
Volatile Solids (\% TS) & 33.5 & 47.3 & 53.5 & 55.7 \\
Ash (\% TS) & 66.5 & 52.7 & 46.5 & 44.3 \\
\hline
\end{tabular}

consequently, an indicator of the potential for methane production.

\subsection{Measurement of Biogas Emissions}

The biogas generated in the studied site contained an average of $45.5 \% \mathrm{CH}_{4}, 32.4 \% \mathrm{CO}_{2}, 3.1 \% \mathrm{O}_{2}, 18.9 \%$ balance gas (i.e., $\mathrm{N}_{2}, \mathrm{H}_{2} \mathrm{~S}, \mathrm{CO}$ ) and emissions differed between quadrants (Table 5). Figure 2 shows the average methane emissions in the four quadrants during the sampling period.

The observed seasonal variation in methane generation is shown in Figure 2, a fluctuation that reinforces the effects of corresponding changes in temperature and precipitation. An increase in methane emission was observed during the rainy season (July-October, weeks 5 to 21) and a decrease in such activity was registered during the dry season (November-June, weeks 23 to 52), the latter due to low water availability. The lower level of methane generation observed in quadrants I and IV suggests the effect of the time of solid wastes confinement and, hence, their degradation stage. In the case of quadrant I, which is the oldest deposit, it was expected that after 20 years a large proportion of the organic fraction had already been degraded. In contrast, in quadrant IV which is the most recent deposit, the methanogenic phase has not yet reached its maximum level.

The average generation of methane observed in the study site $(45.5 \%)$ was below according with the values reported by [33], but some boreholes had values that fall within the range reported in other studies $(58 \%-64 \%)$ $[2,31,32]$. The aforementioned studies also report the influence on methane generation of climate, solid waste composition and type of cover. Most landfills commonly used in developing countries lack infrastructure for capturing methane; nevertheless, being able to identify the level of biogas production is relevant in order to assess both its environmental impact and the economic feasibility of building sanitary landfills having methanecapture systems.

\subsection{Statistical Data Analysis}

The ANOVA test revealed a statistically significant difference $(P<0.05)$ among quadrants in temperature, $\mathrm{pH}$,

Table 5. Composition of the biogas in the site of study (average per quadrant \% volume).

\begin{tabular}{ccccccccc}
\hline \multicolumn{8}{c}{ Composition of Biogas (\% volume) } \\
\hline Q & $\mathrm{CH}_{4}$ & $\mathrm{SD}$ & $\mathrm{CO}_{2}$ & $\mathrm{SD}$ & $\mathrm{O}_{2}$ & $\mathrm{SD}$ & $\mathrm{B}$ & $\mathrm{SD}$ \\
I & 41,3 & 15,1 & 27,7 & 10,3 & 4,4 & 4,9 & 26,5 & 21,0 \\
II & 49,4 & 8,4 & 35,4 & 5,3 & 2,2 & 2,9 & 12,7 & 10,6 \\
III & 48,5 & 5,9 & 35,4 & 4,5 & 2,7 & 2,0 & 13,4 & 8,4 \\
IV & 44,5 & 16,6 & 32,8 & 9,2 & 2,5 & 3,3 & 20,2 & 22,9 \\
\hline
\end{tabular}

Q (Quadrant); SD (Standard Deviation); B (Balance). 


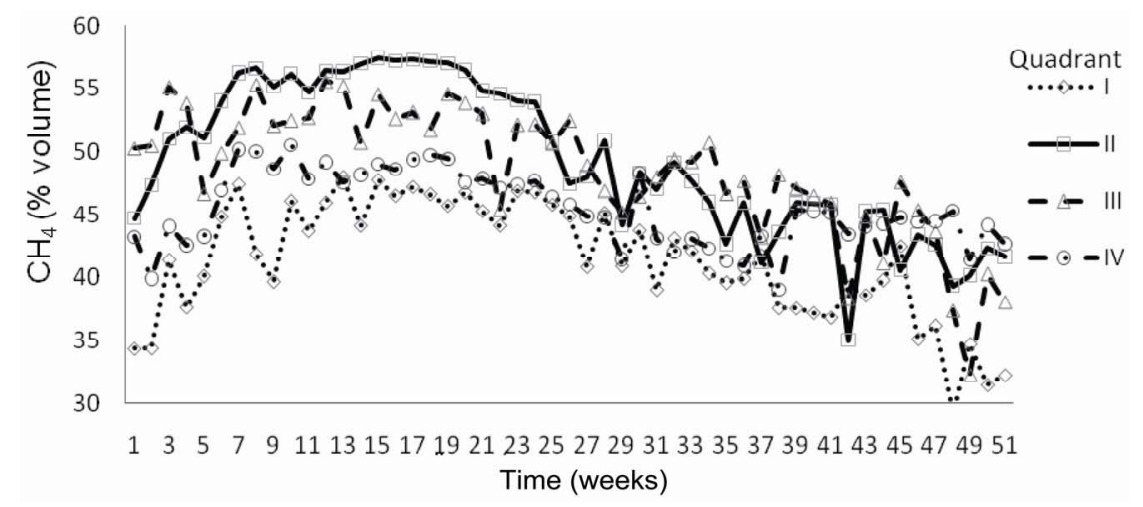

Figure 2. Methane emissions in the site studied (average per quadrant \% in volume).

ashes, VS, organic and inorganic fractions and methane production (Table 6).

The results of the Tukey test for temperature showed a statistically significant difference $(P<0.05)$ between quadrants I and IV with respect to quadrants II and III. The $\mathrm{pH}$ did not show a statistically significant difference between quadrants II and IV, while quadrants I and III indicated such a difference $(P<0.05)$. Ashes did not show a difference between quadrants II and III, while quadrants I and IV did show a statistically significant difference $(P<0.05)$. In the case of VS, quadrants II and III did not show differences but a statistically significant difference was observed between quadrants I and IV $(P<0.05)$. The organic and inorganic fractions were similar between quadrants I and II as between quadrants III and IV, a statistically significant difference existing between both groupings $(P<0.05)$. Concentration of methane showed a statistically significant difference $(P<0.05)$ of quadrant III with respect to the other three quadrants.

Our study showed that the differences in methane production were related to the different stages of degradation of solid wastes, although the effect of residue composition is also to be considered together with the fact that the dump operated without an efficient cover of solid wastes. The statistical analyses corroborate the existence

Table 6. Results of ANOVA for the studied variables.

\begin{tabular}{ccccc}
\hline Source & No. parameters & DF & Sum of Squares & F Ratio \\
\hline Temperature & 3 & 3 & 1331.6439 & 35.5321 \\
pH & 3 & 3 & 10.817776 & 6.5915 \\
Humidity & 3 & 3 & 244.122 & 1.5909 \\
Ashes & 3 & 3 & 5125.5327 & 4.7511 \\
TS & 3 & 3 & 245.23178 & 1.6077 \\
VS & 3 & 3 & 5125.5327 & 4.7511 \\
Organic fraction & 3 & 3 & 2647.4535 & 4.4391 \\
Inorganic fraction & 3 & 3 & 2647.4535 & 4.4391 \\
Methane & 3 & 3 & 2018.2282 & 28.3443 \\
\hline
\end{tabular}

of a statistically significant difference between sampled quadrants.

\section{Conclusions}

1) Statistical analyses reveal heterogeneity of solid waste composition within the studied site, differences which are due to differences in confinement chronology.

2) A larger amount of organic fraction was found in more recent quadrants, likewise, the ANOVA and the Tukey test showed a statistically significant difference between quadrants corroborating the effect of time of confinement of solid wastes, despite the deficiencies in their covering.

3) The contents of VS observed in the solid wastes together with the statistical analyses of the four studied quadrants confirm existing differences in organic matter content (degradability) and in degradation stages of the latter.

4) Differential methane generation between quadrants and the statistical analyses corroborated the effect in biogas production of solid wastes composition (organic matter and its degradability) and of the time elapsed since their confinement.

5) The way in which variables were analyzed over time allowed for corroboration of differences in methane generation, not only between different sites but also within the same site.

6) Studies like the present are relevant to increase the information regarding biogas production in final disposal sites that have no control over the variables known to have an effect on methane generation.

\section{References}

[1] IPCC, "IPCC Guidelines for National Greenhouse Gas Inventories, Prepared by the National Greenhouse Gas Inventories Programme," In: H. S. Eggleston, L. Buendia, K. Miwa, T. Ngara and K. Tanabe, Eds., Intergovernmental Panel on Climate Change, Waste IGES, Japan, Vol. 5, pp. 3.1-3.44. 
[2] C. Chiemchaisri, W. Chiemchaisri, S. Kumar and J. Hettiaratchi, "Solid Waste Characteristics and Their Relationship to Gas Production in Tropical Landfill," Environmental Monitoring Assessment, Vol. 135, No. 1-3, 2007, pp. 41-48. doi:10.1007/s10661-007-9706-2

[3] S. E. Borglin, T. C Hazen, C. M. Oldenburg and P. T. Zawislanski, "Comparison of Aerobic and Anaerobic Biotreatment of Municipal Solid Waste," Journal of the Air and Waste Management, Vol. 54, 2004, pp. 815-822.

[4] E. R. Fielding, D. B. Archer, E. C. Demacario and A. J. L. Macario, "Isolation and Characterization of Methanogenic Bacteria from Landfills," Environmental Microbiology, Vol. 54, No. 3, 1988, pp. 835-836.

[5] J. H. Wilshusen, J. P. A. Hettiaratchi and V. B. Stein, "Long-Term Behavior of Passively Aerated Compost Methanotrophic Biofilter Columns," Waste Management, Vol. 24, No. 7, 2004, pp. 643-653. doi:10.1016/j.wasman.2003.12.006

[6] S. Kalyuzhny, M. Gladchenko and E. Epov, "Combined Anaerobic-Aerobic Treatment of Landfill Leachates Under Mesophilic, Submesophilic and Psychrophilic Conditions," Water Science and Technology, Vol. 48, No. 6, 2003, pp. 311-318.

[7] R. Rajasekaran, R. Muragesan and A. Palanisamy, "Influence of Temperature on Microbiological Numbers and Biogas Production of Some Anaerobically Digested Waste," Agricultural Wastes, Vol. 17, No. 2, 1986, pp. 83-89. doi:10.1016/0141-4607(86)90047-8

[8] F. L. Wang and J. R. Bettany, "Methane Emissions from Canadian Prairie and Forest Soils under Short Term Flooding Conditions," Nutrient Cycling in Agroecosystems, Vol. 49, 1997, pp. 197-202. doi:10.1023/A:1009758308457

[9] R. Munasinghe, "Effect Hydraulic Retention Time on Landfill Leachate and Gas Characteristics," Ph.D. Thesis, University of British Columbia, Vancouver, 2003.

[10] M. T. Orta, R. R. Cruz, V. N. Rojas, R. I. Monje and G. J. Sánchez, "Determination of Field Capacity of Municipal Solid Waste with Surcharge Simulation," Waste Management \& Research, Vol. 21, No. 2, 2003, pp. 137-144. doi:10.1177/0734242X0302100207

[11] C. Zeiss and W. Major, "Moisture Flow through Municipal Solid Waste: Patterns and Characteristics," Journal Environmental Systems, Vol. 22, No. 3, 1993, pp. 211- 231.

[12] M. S. Hossain, M. A. Gabr, F. Asce and M. A Barlaz, "Relationship of Compressibility Parameters to Municipal Solid Waste Decomposition," Journal of Geotechnical and Geoenvironmental Engineering, Vol. 129, No. 12, 2003, pp. 151-1158. doi:10.1061/(ASCE)1090-0241(2003)129:12(1151)

[13] I. Bergman, M. Klarqvist, and M. Nilsson, "Seasonal Variation in Rates of Methane Production from Peat of Various Botanical Origins: Effects of Temperature and Substrate Quality," Microbiology Ecology, Vol. 33, No. 3, 2000, pp. 181-189. doi:10.1111/j.1574-6941.2000.tb00740.x

[14] C. Bernard and G. Merlin, "The Contribution of Ammonia and Alkalinity to Landfill Leachate Toxicity to Duck- weed," The Science of the Total Environment, Vol. 170, No. 1-2, 1995, pp.71-79. doi:10.1016/0048-9697(95)04563-G

[15] L. Márquez and C. I. Watson, "Effect of Intermediate Soil Cover on Municipal Solid Waste Decomposition," Water Science Technology, Vol. 48, No. 4, 2003, pp. 245-248.

[16] N. R. E. Méndez, S. R. Cachón, R. M. Sauri and B. Casti1lo, "Influencia del Material de Cobertura en la Composición de Lixiviados de un Relleno Sanitario," Revista de Ingeniería, Vol. 6, No. 2, 2002, pp. 7-12.

[17] R. E. Klink and R. K. Ham, "Effects of Moisture Movement on Methane Production in Solid Waste Landfill Samples," Resource Recovery and Conservation, Vol. 8, No. 1, 1982, pp. 29-41.

[18] G. P. Korfiatis, A. C. Demetracopoulus, E. Bourodimos and E. G. Nawy, "Moisture Transport in a Solid Waste Column," Journal of Environmental Engineering, Vol. 110, No. 4, 1984, pp. 780-796. doi:10.1061/(ASCE)0733-9372(1984)110:4(780)

[19] V. Francois, G. Feuillade, G. Matejka, T. Lagier and N. Skhiri, "Leachate Recirculation Effects on Waste Degradation: Study on Columns," Waste Management and Research, Vol. 27, No. 9, 2007, pp. 1259-1272. doi:10.1016/j.wasman.2006.07.028

[20] M. Swati, J. Kurgan and R. Nagendran, "Bioreactor Landfill Lisymeter Studies on Indian Urban Refuse," Proceedings of the Tenth International Waste Management and Landfill Symposium, Sardinia, 3-7 October 2005, pp. 229237.

[21] G. T. Ellis, J. Park, E. Debik and S. Smith, "Evaluation of Leachate Treatment and Recycle Options at the Boone County Landfill," Proceedings of the Twenty International Conference on Solid Waste Technology and Management, Philadelphia, 3-6 April 2005, pp.102-156.

[22] N. Sanphoti, S. Towprayoon, P. Chaiprasert and A. Nopharatana, "The Effects of Leachate Recirculation with Supplemental Water Addition on Methane Production and Waste Decomposition in a Simulated Tropical Landfill," Journal of Environmental Management, Vol. 81, No. 1, 2006, pp. 27-35. doi:10.1016/j.jenvman.2005.10.015

[23] S. S. Chung and C. S. Poon, "Characterization of Municipal Solid Waste and Its Recyclable Contents of Guangzhou," Waste Management \& Research, Vol. 19, No. 6, 2001, pp. 473-485. doi:10.1177/0734242X0101900603

[24] D. R. Reinhart and A. B. Al-Yousfi, "The Impact of Leachate Recirculation on Municipal Solid Waste Landfill Operating Characteristics," Waste Management \& Research, Vol. 14, No. 4, 1996, pp. 337-346.

[25] B. M. Sinan, A. Demir and B. Ozkaya, "Influence of Leachate Recirculation on Aerobic and Anaerobic Decomposition of Solid Wastes," Journal of Hazardous Materials, Vol. 143, No. 2, 2007, pp. 177-183. doi:10.1016/j.jhazmat.2006.09.012

[26] D. T. Sponza and O. N. Agdag, "Impact of Leachate Recirculation and Recirculation Volume on Stabilization of Municipal Solid Wastes in Simulated Anaerobic Bioreactors," Process Biochemistry, Vol. 39, No. 12, 2004, pp. 
2157-2165. doi:10.1016/j.procbio.2003.11.012

[27] M. A. Barlaz, "Microbiology of Solid Waste Landfills," In: A. C. Palmisano and M. A. Barlaz, Eds., Microbiology of Solid Waste, CRC Press, Boca Raton, 1996, pp. 541557.

[28] D. R. Reinhart, P. T. McCreanor and T. G. Townsend, "The Bioreactor Landfill: Its Status and Future," Waste Management and Research, Vol. 20, No. 2, 2002, pp. 172186. doi: $10.1177 / 0734242 X 0202000209$

[29] A. Gendebien, M. Constant, E. Ledrut-Damanet, H. Nyns, J. Willumsen, R. Butson, G. Fabry and Ferrero, "Lanfill Gas from Environment to Energy," Commission of the European Communities, Luxembourg, 1992.

[30] H. Scharff and J. Jacobs, "Applying Guidance for Methane Emission Estimation for Landfills," Waste Management, Vol. 26, No. 4, 2006, pp. 417-429.

[31] G. Hernández and C. Duran, "Biogas Production in a ClosedDown Sanitary Landfill," Ingeniería y Ciencias Ambientales: Investigación, Desarrollo y Práctica, Vol. 1, No. 1, 2006, pp. 1-15.

[32] K. Wang-Yao, S. Towprayoon and S. Jaroenpoj, "Estimation of Landfill Gas Production Using Pumping Test," Proceedings of the Joint International Conference on Sustainable Energy and Environment (SEE), Hua Hin, 1-3 December 2004, pp. 340-343.

[33] T. Tolaymat, R. Green, G. Hater, M. Barlaz, P. Black, D. Bronson and J. Powell, "Evaluation of Landfill Gas Decay Constant for Municipal Solid Waste Landfills Operated as Bioreactors," Journal of the Air and Waste Management Association, Vol. 60, No. 1, 2010, pp. 91-97. doi:10.3155/1047-3289.60.1.91

[34] I. Israde, O. Buenrostro and A. Carrillo, "Geological Characterization and Environmental Implications of the Placement of the Morelia Landfill, Michoacán, Central México," Journal of the Air and Waste Management Association, Vol. 55, No. 6, 2005, pp. 755-764.

[35] Secretaría de Comercio y Fomento Industrial, "Mexican
Norm NMX-AA-022-1985. Environmental Protection-Soil Pollution-Municipal Solid Residues by-Products Selection and Quantification," San Ysidro, 1985, pp. 1-5.

[36] Secretaría de Comercio y Fomento Industrial, "Mexican Norm NMX-AA-025-1984. Environmental Protection-Soil Contamination-Solid Residues-pH Determination-Potentiometric Method," San Ysidro, 1984a, pp. 1-5.

[37] Secretaría de Comercio y Fomento Industrial, "Mexican Norm NMX-AA-016-1984. Environmental Protection-Soil Pollution-Municipal Solid Residues-Humidity Determination," San Ysidro, 1984b, pp. 1-5.

[38] APHA, American Public Health Association, "Standard Methods for the Examination of Water and Wastewater," 12th Edition, Washington DC, 1998.

[39] Secretaría de Comercio y Fomento Industrial, "Mexican Norm NMX-AA-018-1984. Environmental Protection-Soil Pollution-Municipal Solid Residues-Ashes Determination," San Ysidro, 1984c, pp. 1-5.

[40] O. Buenrostro, G. Bocco and G. Bernache, "Urban Solid Waste Generation and Disposal in Mexico. A Case Study," Waste Management \& Research, Vol. 19, No. 2, 2001, pp. 169-176. doi:10.1177/0734242X0101900208

[41] O. Buenrostro and G. Bocco, "Solid Waste Management in Municipalities in México: Goals and Perspectives," Resources Conservation and Recycling, Vol. 39, No. 3, 2003, pp. 251-263. doi:10.1016/S0921-3449(03)00031-4

[42] A. Yilmaz and F. Atalay, "Modeling of the Anaerobic Decomposition of Solid Waste," Energy Sources, Vol. 25, No. 11, 2003, pp. 1063-1072. doi:10.1080/00908310390233586

[43] R. Mehta, M. A. Barlaz, M. Asce, R. Yazdani, D. Augenstein, M. Bryars and L. Sinderson, "Refuse Decomposition in the Presence and Absence of Leachate Recirculation," Journal of Environmental Engineering, Vol. 128, No. 3, 2002, pp. 228-236. doi:10.1061/(ASCE)0733-9372(2002)128:3(228) 